\section{ECT and the media}

DeAr Sirs

We would like to bring to your attention a negative and damaging portrayal of mental illness, the mentally ill, and those who provide care for them, in the new Disney film Return to $\mathrm{Oz}$. In particular, electroconvulsive therapy is presented in a greatly inaccurate and frightening manner.

Briefly, Dorothy, who has been unable to sleep since the tornado (in The Wizard of $\mathrm{Oz}$ ), is taken to a "lunatic asylum' and threatened with 'electric treatment' to help her sleep and to make her forget $\mathrm{Oz}$-in other words, to obliterate her memory and imagination. Tension and horror mount as she is connected to the machine and the switch is about to be thrown, when luckily (sic) the power is cut by a storm and she is saved. She runs screaming from the gloomy house with its shrieking patients, pursued by a black-clad nurse who later becomes the bad witch.

The messages are painfully clear: ECT is harmful, dangerous, and frightening; it can be given to children without informed consent; mental hospitals are places of horror; doctors and nurses are not to be trusted; ECT will destroy your memory and imagination. The effect on psychiatric patients who have agreed to ECT but are dreading it can readily be envisaged; the effect on children who may well become such patients in the future must be devastating.

It is our contention that psychiatric patients are in a specially vulnerable position, including the already negative image of ECT in the public mind, and that any such damaging portrayal should be immediately withdrawn on request. This Association, together with its sister groups across the English-speaking world, is requesting the support of the medical, in particular the psychiatric profession, in having Disney withdraw the film or at least replace the opening sequence. It is of interest that the opening sequence is the only part of the film not true to the story line of Baum's book Return to Oz.

Any publicity you could give to this issue, or any direct communication you wish to have with the Disney Studios, would be greatly appreciated.

JOHN HODGKINSON Medical Adviser

Manic-Depressive Association (York Region)

Newmarket

Ontario, Canada

\section{South African psychiatry}

DeAr SirS

Whatever the immediate precipitants of the policy statement from the Society of Psychiatrists of South Africa, it is difficult to believe that it would ever have been issued, let alone conceived of, were it not for the sustained campaign from Britain and the United States condemning the employment of mental health services in furthering the policy of apartheid. I know from personal contacts with some (white) South African psychiatrists how much they value international pressure on their professional leaders, reticent as they are to abandon current racist practices; $\mathrm{Dr}$ Bewley (Bulletin, October 1985, 9, 202-203) is unduly modest about the powerful influence the College wields in such matters. Endorsement of the theoretical ideas put forward by the SPSA is fine; what many members of the College are wondering is-what initiatives is the SPSA actually carrying out and what further encouragement is the College offering to ensure real change?

All Saints Hospital

ROLAND LitTLEWOOD

Birmingham

DeAR SIRS

In his reply to Dr Sashidharan (Bulletin, October 1985, 9, 202-203), the President, Dr T. H. Bewley, has unwittingly contributed further to a widespread misunderstanding which exists concerning the College's position over abuses of psychiatry in general, and of South African psychiatry in particular.

Dr Bewley refers to 'the College's Special Committee on Abuse of Psychiatry'. However, the committee to which he refers is the fact 'the Special (Political Abuse of Psychiatry) Committee'. The distinction is of great importance since the committee in question has strictly limited its remit to the misuse of psychiatry for political purposes. In its report on South Africa (Bulletin, June 1983, 7, 115), for example, the committee refers to discriminatory practices but adds that 'this issue is beyond our remit'.

I believe that the present committee's remit is too narrow and that the College should establish a committee which could examine broader issues of ethical and other forms of abuse. The violation of human rights involving tens of thousands of patients in Japan's private mental hospital system is a case in point. ${ }^{1}$ The present special committee would certainly consider the problem as beyond its remit since the origins of these abuses are financial rather than political. However many members must feel that the College's intervention would be as justified in this case as for that of the political abuses in the Soviet Union.

The College should indeed establish a Special Committee on the Abuse of Psychiatry. The President however does a disservice by suggesting that it already has one. As he himself points out to Dr Sashidharan, factual accuracy matters.

Institute Universitaire de Médecine Légale

T. W. HARDING

Geneva, Switzerland

REFERENCE

'INTERnA Tonal Commission Of JURISTS (1985) Human Rights and the Treatment of Mental Patients in Japan: Conclusions and Recommendations of an Expert Mission. Geneva.

IThe remit of the Special ( Political Abuse of Psychiatry) Committee is currently under review-Eds.J 